\title{
Crime Prevention Techniques and Crime Prevention in Turkey
}

\author{
Dr. Ufuk Ayhan \\ Turkish Police Academy
}

\begin{abstract}
Conceptually, security concept is always tend to expand its own limitations. Current global events, emerging new situations and resulting needs in this area often make the changes obligatory and inevitable. Today, the fight against crime and criminality follows a path which aims to identify and clarify the crime begining from the emergence of the criminal activity until the capture and detention of its actors, and finally dealing with them through judicial process and prison. However, often its social costs and damage as well as its impact on the sense of trust in the community have been ignored. This study analyzes and assesses modern techniques which are available to use against criminal activities and organizations.
\end{abstract}

Keywords: Crime Prevention, Public safety, Security.

\section{INTRODUCTION}

About security, the first thing that comes to mind is the protection of the state and its basic elements. Second is the approach including the preventive and juridical process achiving by the arm guard and the general law enforcers. However, in today's society, the concept of security including the individual areas of economic and social dimension has been dominating the field. Rather than only being against a thief that entered the house or in the street against a beggar to be bothering them, the individual safety has a wide range of the general living space such as the environmental health, zoning and housing policies, noise, natural disasters, terrorism that is creating fear and anxiety, planet security, chemical and biological threats. Basically, the rules emerging for the social order, harmony, and the development are also the guarantee of a safe life. Of course, in general, in addition to the external and internal safety, the term safety can be detailed as social, economic, cultural and environmental safety.

As it is known Maslow's hierarchy of needs are listed as physiological, safety, belonging, esteem and self-actualization. In each circumstance, our subject safety need, "Conservation and protection of the resulting desire tended to urge the institutionalization of the concept of sefety is forced to achieve a horizontal social relation point. On the basis of this, the 
effective need to take the vertical preventions in the public safety approach lies." ( Demir, 2002:15 ). For state, the term safety can be summarized in three main subjects. These are; the national security that aims to ensure the continuation of the national interests and the constitutional law security; the public safety that aims to protect the public safety and the individual's safety and the living space safety safety or in other words the public peace safety that ensure the safety of the Daily lives of individuals within the area and the time period.

The living space safety or in other words the public peace services defines the general terms of the relations of the individuals with the other individuals and with the public services except the concepts such as the state safety or public peace that has more outstanding features in each stage of the Daily life, in the transportation vehicles, in the working places or in their houses.

Urbanization, advances in technology, advances in communication tools, Globalization; and the emergence of the business section along with industrialization has increased the dependence of people with each other. In the industrial society, man's relationship with man has left its place to the relationship of the society with the community (Erdem, 2001).

\section{CRIME AND CRIME PREVENTION TECHNIQUES}

Directly and indirectly, the concept of crime affects and interests the society as a whole. According to the year - end 2013 datas, \% 77.2 of our country's population live in urban areas and $\% 22.7$ of the population live in rural areas. Through population growth and internal migration, population density especially in big cities clustered together had increased crime rates and gave a negative differentiation in the perception of security.

"In nineties, the concepts such as the perception of crime clarification management, capture, criminal convictions, fines and detention centers and justice mainly shifted towards the development of crime problem solution oriented preventive policies rather than direct criminal arrestment. Now the real work of security became a

Inquipy 2016/1 problem that is searched to be solved alongside with the official law enforcement local governments, non-governmental organizations, universities and the most important inter-sectoral collaboration involving the citizens. In this direction ( Geleri, 2010:26):

- Detection of the factors that led to the processing of crime and the elimination of these factors,

- The processing of the zoning plan and carry out works related to the physical arrangement in order to deter criminals and to complicate the processing of crime,

- Works done to eliminate the fear of crime,

- To raise awareness and to inform citizens about the crime prevention, 
- The provision of assistance and support services to the victims of crime,

- Conducting studies on ex-convicts have a vital importance."

Individual and public safety is important for the visibility of the offered services. Having the foot and motorized patrols in the preventive actions have a vital importance for the presence of both state authorities as well as individuals themselves feel safe. Without connecting the patrol services to a certain routine, a system that continuously goes on can give effective results within a certain time and place. It is also known that, taking these measures in a wide range of different sectors of society also has a special importance to create deterrence on the potential crimes and crime prevention alongside special attention in apprehending criminals (Geleri, 2003: 69 ).

\section{CRIME PREVENTION WITH A COMPARATIVE PERSPECTIVE}

If we compare it with the United States of America, in the USA, the police organizational structure has earned a special feature by its partition and diversity. The police is the symbol of the local government that rely on the grassroots ( Gleizal, Domenach and Journes 2000: 235 ). In the federal states, the state has seperate police organizations in the state levels. In the USA, while this police force is about 450 thousand ( Gleizal, Domenach and Journes, 2000: $235-236$ ) this number is about 48.950 in the New York city only ( Binnninger and Dreher, 2004: 251 ). In the year 2005, the number of police officers in the New York Police Department is 39.110 ( NYPD, 2006 ).

In the USA, the basic functions of the police department is team (patrol), criminal investigation, traffic control, to avoid harmful habits and indecent acts and to control juvenile delinquency and for these duties, line departmens are formed. On the other hand, in the state level police organizations, there are seperate departments for these functions. In order to ensure efficiency in the execution of these tasks, the responsibilities were decentralized by the district stations. Patrol is an indespensible way to fullfil the security services. As known, the patrol services has a very effective role in the services with its ready for service, preventive functions (Bahadır, 1985: 19 - 21).

While having 440 officers in the year 1924, today, FBI has approximately 21 thousand officers. From the Second World War to the present day, FBI has been working on the inter state nature crimes against the federal laws such as kidnapping, drug trafficking, the fight against internal corruption and counter-espionage. Withthe laboratories, identification units, computer data centers 
in its excisting structure, it makes significant contribution to the local forces. And since 1989, the FBI officers can arrest the criminals without having the consent of the federal state (Glezia, Domenach and Journes, 2000: 236).

The New York Police Department was formed in the 19. Century by modelling the London Metropolitan Police Department and now is the biggest and the largest metropolitan police department of the United States of America. The New York Police Department is giving legal protection and investigation services in the five central boroughs of the New York City. According to the own definition of the Department, its dut is "to apply the law, keep the peace, reduce fear, to create a safe environment, to prevent and to investigate the crime". Being in the New York Metropolitan Police Department but working as a seperate department, the New York Transit Police is responsible for protecting the transportation network of the New York City investigating the events occured in this network and the Housing Police is only responsible for the prior police services such as protecting the public peace in the certain areas built buildings and districts made by Federal Government or the State Government decisions, crime prevention, offenders identify and arrest, community violence prevention, protect the rights of people, ensure the safety of life and property, the protection of public health, the prevention of violence and breaches of law rules, arrest those who violate the rule of law and fingerprints of people arrested and taken their photographs (NYPD, 2006).

When we consider the New York City in terms of security, individuals feeling themselves safe and the fight against crimes, we see that, especially until 1990s, there is an increase in crime rates and also an increase in the fear of incurring crimes but by the 1990s, as the beginning of the new understanding to provide security and fight against crime, serious gains were observed on crime and delinquency.

The underlying principles of this success are; "to be close to the scene as possible, the active information gathering and inquiry work, convenient and constantly supervised in accordance with guilt tactics, rapid police reaction and progressive police measures, zero tolerance against 'the petty criminals and those who disturb order' for example; in the streets, stopping the use and transport of weapons, school and driveways youth violence suppression, fighting against drug crimes, special teams fighting against drug abuse, control of public buildings and spaces, taking the small sellers' money and vehicle confiscation and prohibition of their entry into the field. In all these works, the coordination with the court house and the the speedy trial has a very important role in these works (Binnninger and Dreher, 2004: 253 - 4).

In New York, according to the "zero tolerance" policy; 
intimidation and deterrence of the criminals strategy has worked. In the past, beg in public transport, passenger disturbance, trafficking of women, making small toilet in public areas were the everyday events that people have to live with, as Giuliani became the mayor, until 1990s, by incarceration of people disturbing public order and peace for a few days of, disposal of the drug dealers from the streets under pressure from police, preventing of carrying the weapons that could have grave consequences and leaving these weapons at home, to ban the vehicles from the traffic that is creating excessive noise, cooperate closely with other agencies about construction, traffic, youth and health issues and immediate prevention of gang graffiti used in the communication of the gangs has created important results (Binnninger and Dreher, 2004:254).

The five boroughs of the New York City has been increased to 8 and for each borough, there is a commander (can be compared with the Polic Director). In addition to this, there are 76 Precints (the units - zone that gives security services).

In the United States of America, the "Public Guards" system which is a patrol sevice of the citizens and built in the 19. Century (Binnninger and Dreher, 2004: 257) is still in force today and Shaquille O'Neal is a reserve police in a this type of program (Shaq sworn, 2006). Beside this, pedestrial patrol system also yielded significant results in the prevention of crime and delinquency. In the New York scale, ensuring the social order, easily investigating the criminals by direct connection with the local community and by knowing the addresses of the citizens, its being increasing the trust has gained important advantages. But the staff not willing to work in these services becomesa major handicap (Binnninger and Dreher, 2004: 267).

In england, by " the foot patrols, the community watch schemes, the consulative commitiees and the community policing" studies, as the police acts consensually rather than use of force, creates important effects in the participation of the citizens (Aydın, 2002: 105).

The London Metropolitan Police Authority consists of 23 members. 12 of them are authorized by the Mayor on behalf of the London Assembly, 4 of them are the Conservators of Peace authorized by the Home Office, 7 of them are independent members an one of these 7 members is authorized by the Minister of the Internassl Affairs. For the other members, an open announcement is made. The Chairman of the Metropolitan Police Authority is elected by the members and all the members can be candidate for the elections. Each member is in relation at least with one municipality. So, wherever you live, one of the members has closely related with the police services in your region (London Metropolitn Police Authority, 21.12.2005). 
In England, USA and Holland, by the Blue - point Programme, there is an effective reduction in offenses. In the core of this program the pre-school and after-school socialization studies, visiting the risky families and educating the heads of these families, providing resources to the families which has disadvantages in education and having educational works are aimed (Reno and other, 2000: 6). About the home and car theft; "Cocoon Neighbour Surveillance Program" was developed. With the Zero Tolerance approach, by not allowing the petty crimes, a success has been gained in preventing the major crimes (Binnninger and Dreher, 2004: 255 - 6).

In the USA, in the doctrine of criminology, the "root causes" of crimes are found as poverty, unemployment, social inequality, discrimination and social deficiencies of families and groups resulted by the lack of the families being organized. In addition to this, in the USA, by the "Tipping Point" theory, crime has been likened to an epidemic and as the crime wave could easily turn to flood, it has to be stopped immediately. In this theory, the aim is based on the suppression of the crime before it reaches to a serious level (Binnninger and Dreher, 2004: 252). Again, in the USA, by the beginning of the 1994, by using the statistical datas in the fight against crime (COMPSTAT), crime-fighting activities have been accelerated.

If we make an economical assesment of the crime prevention programmes in the USA; according to the records of the year 1999, it shows that when their is an increase in the employment, there is a direct increase in the tax revenues, if there is an increase in the orderly life rates, there is an increase in the house rents and there is a dicrease in the costs of capture, arrest, incarceration and trial. So, the gain of each dollar spent changes between 1.06 dollar to 7.16 dollar. Also by reducing the crime areas, each dollar can have a return between 1.83 dollar to 7.14 dollar. In the developed Western Europe Countries and in the USA, in recent years, spending on education and health spending goes over the justice and delinquency is the result of this approach (Reno and others, 2000: 7 - 8).

Based on these comparative applications, in our country, by 2016/1 preparing a detailed action plan with determining the aims clearly, of cource together with the public support and the continuity of the partnership, the various sectors should take responsibilities according to their contribution rates. As in the USA, in the process of fight against crimes, rather than solutions depending on the law regulations and trials, giving focusing on the studies on crime prevention in the work areas such, in the schools, in the social services and in the health services, the preventive security services can give more benefit and can be more economical and because of this reason, in the fight against crimes, legal or non - govermental 
organizations, all the social units should take responsibilities and they are required to take their parts in these process.

Especially in the USA and in some European countries, citizens spend so much money on alarm systems, insurances and house protection services to feel safe. Except this, especially in the countries such as USA, England, Holland, France and New Zealand, it is found much more important to make investments on the children in the pre school and after school development programs instead of spending on the security investments. Yet, there is report in this issue that is prepared by the USA National Crime Prevention Committee in 1999. According to this type of social content programs, in the Western Europe countries, in Australia, Canada and in the United States, compared to 70sand 1960s, in 1990s, a gradual decline has been achieved in the crime rates.

\section{PREVENTIVE POLICING IN CRIME FIGHTING}

About the fight against crime, if we look at the New York City model; as there is a huge increase in the crime and delinquency rates aspecially in the 1970 s and 1980 s; today, the policing services has focused on the detailed on social intelligence, statistics, technological and community policing and by the beginning of the 1990s, very importants success has been gained in this area. In the policing services and security policies, the new and different struggle techniques such as "Broken Windows" (not ignoring even the smallest details, to be dealt with each types of guilt), "Zero Tolerance", "Intelligance - Led Policing", "Community Policing", "Problem Oriented Policing" (Billante, 2003: 2), Police and Neighbour Safety, Community Policing (Binnninger and Dreher, 2004: 260 - 1) has been applied.

In the period started with the word "Law \& Order", betwen the years 1994 and 1995, the total crime rates in the USA has declined by $\% 2$ and has declined in the New York City by \% 14.5. In the New York City, the decline in the crimes has came to the $\% 70$ level in 1996 and in the end of the 1990s, this level came to the \% 68 (Binnninger and Dreher, 2004; 252 - 1).

In the developed Western Countries and in the USA, Canada and Australia, as the studies done and their results have a parallelism with the internal Dynamics and the social structures of these countries, in modelling, if we ignore the differences in the social structure and take these models directly or create the similar models with these programs, these approach will turn us into the lighhouse keepers looking for darkness in the day light. In here, the proper thing to do is to perceive what is going on in the world and concentrate on our own model after taking the lessons from the results of the other models. 


\section{CRIME PREVENTION TECHNIQUES}

\subsection{Theoretical Approaches in Crime Prevention}

The crime prevention techniques are seperated into three main categories a traditional, liberal and radical approach. As in the crime prevention levels and as in the other approaches, each of these approaches has their own understanding and applications.

1. Traditional Approach: The traditional approach emphasizes the law, government and public authority. It argues that if the penalty of a criminal taking after the crime wil be much more than the profit (benefit) of the crimal will tend to gain, the criminal will desist from committing crimes. So here law prevails can be applied more effectively by the deterrent penalties. On the other hand, this method also argues that, because it is not possible to prevent the crimes only by the individual efforts of the police, the citizens also should give support to the police. (Bese and Geleri, 2013: 37).

2. Liberal Approach: In this model, crime is seen as a social problem. According to this approach, the disadvantages in the environmental of the individual are important factors in the formation of guilt. Rather than the crime, the liberal model focuses on the potential crime groups that are prone to commiting crimes. Within this context, it is said that, by increasing the legal and statutory opportunities of the individuals and the groups, the crimes can be prevented ( Bese and Geleri, 2013; 37 ).

3. Radical Approach: The radical approach defends that the inequalities in the society is the main objective in creating crimes. In a social structure if there is social justice andif economic income distribution is carried out in a fair manner, people will not have any reason to commit crimes ( Bese and Geleri, 2013: 37 ).

\subsection{Crime Prevention Models}

Right to life is at the beginning of the most basic human rights. But, right to life can be achieved only in safe places. This aspect of safety and security issues always has been one of the priority issues since the existence of mankind. And the crime prevention has taken its placein the literature by the beginning of the crime problem. Today, the new thing is the content of the crime prevention approaches and efforts, their sizes and seriousness (Bese and Geleri, 2013: 38).

a) Proactive Model: It defines the prevention of crimes by the active works before they are committed. It includes the elimination of the favorable opportunities to commit crimes and the strategies that weaken the offenders recidivism thoughts and commitments. 
In this manner, this approach consists of the works applied for the elimination of the factorsaffecting the commitment of crimes or reducing these factors to the minimum levels (Bese and Geleri, 2013: 37). Crime struggle in cooperation is developed by the American industrial experiences. Basically this strategy depends on collecting datas, evaluation, analysis, determination of the problem arising zones, preparation of the political choices and plans and finally applying these plans and monitoring their results (Bese and Geleri, 2013: 38).

The proactive model addresses the pre crime period. In general meaning, as it is a preventive approach, by taking all the necessary steps, it tends to take all the required preventions and prevent the crime or the event and if the crimes can not be prevented it tends to reduce the losts to the minimum level (Bese and Geleri, 2013: 38).

In the proactive model, the main aim is to eliminate the reasons that drive people to crimes and builds a social structure in which evey one obey the rules and being god citizens. Meaning that, having so strong and healthy social, economic and cultural structure that no one even have an idea of committing crime. Ideally, there is a philosophy that tend to prevent even the idea of committing crime. This approach defending the struggle against the reasons that drive the people committing crimes can only be applied by the active participation of the society and their acceptance and supports (Bese and Geleri, 2013: 39).

b) Crime Prevention Model: The policing services that aims to prevent the crimes and cathing the criminals and the center of the interest of this struggle has two sides; police and the criminals. Crime is an event that effects the people deeply and has the negative effects on people for a long period and maybe until the end of their lives. As its target group has a very wide range, this issue across the board should be addressed in a comprehensive way. To occur the crime, the following three issues should be ready together andshould be met (Bese and Geleri, 2013: 40): Target / victim (individual, building, institution, object), Criminal (The one thet commits the crime), Situation / Opportunity (The situations in which the criminal and the target meets; environment and the place). When we talk about the role of the police in the struggke against crimes, in general, the first thing that comes to minds is 'catching the criminals'. Whereas, the main task of the police is to prevent the commitment of crimes. In the A paragraph of the 1. Clause of the Article 2 of the 2559 numbered Law on Police Duties and Powers, the task of the police is defined as "preventing the actions under the provisions of this Act before processing of transactions that are not applicaple with the laws, regulations, government orders and public orders". As it can be seen in here, ensuring public order and security, providing preventive services before the crime has been 
recognized as one of the primary duties of the police and this issue was also seated in a legal framework (Bese and Geleri, 2013: 40 ).

After the crime, public damages or individual damages are in question. As crimes are committed, harm is given to the individuals and ore important there is a social harm. In this situation, as the offenders are catched and registered with the guilt of the people convicted by the court are sent to prison to serve their sentence. In a this kind of situation, the cost of the person to the society hugely increases. In this context,: as the individuals participation to the production process will come to an end, his / her production capacity will become unusable. As because the individual will be only a consumer in the prison, the money of the poeple giving taxes will be spent for the fod, water, heat, bed, bath, health, security etc. expenses and in addition to this, the prison will have to hire many professionals from various occupations such as guards, prison director, teachers, priests, workers, psychologists, social workers and prosecutors and this will led to an additional cost item for the society. (Bese and Geleri, 2013: 41). So, the preventive approaches has a very importance and function in general for the social life, public order and country economy and in special for the crime struggle and prevention of crimes.

There is a thin line between the proactive model and the preventio model differs. In the Proactive Model, the main aim is to create and develop the socio-economical, political, cultural and educational oriented projects and models that will eliminate the people having even the idea of committing crimes. But, in the Prevention Model, despite these studies and programs, if the people have the idea of committing crimes, this approach tends to prevent them to put their ideas into practice (Bese and Geleri, 2013: 41).

c) Juridical / Reactive Model: In the context of the crime investigation and research policing actions,collecting the informations, catching, detention, interrogation and trial work take place in this model as a whole. According to the Brantingham and Faust, this approach is determined as fire department (fire extinction) policing. To realise these actions, the occuring of the juridical case or a crime is the pre requisite. In this model, policing takes place after the commitment of the crime, police intervene to the event immediately, takes the necessary preventions, by using his / her occupational experiences, tries to clarify the case. The inquest is an action that needs so much personnel in policing actions (Bese and Geleri, 2013: 41).

d) Repair (punitive / corrective) Model: Repair / punitive model is a stage emerges by making the necessary inquiries after the crime, arresting the criminals convicted by the courts. In this approach, it is considered important to prevent the people commiting crimes again by punishing the criminals and by taking the corective 
actions. After prison, the prisoners should be monitored with a close interest by the social services. In this manner, the prisns being in the first place, the punitive justice system as a whole is the most important part of this approach. This situation brings the two important opinions (Bese and Geleri, 2013: 43).

First one is the strict approach that defends criminals to be punished in the harshest way. It is thought that, the criminals should be punished in the harshest way and so that they will take the necesery lessons by this way and will not tend to commit crime again. It says that, the harshest way of punishment will also deter the other people that have the idea of commiting crimes (Bese and Geleri, 2013: 43).

e) Application Stages of Crime Prevention Programs: Crime prevention by deterrence method is the central point of the prevention approaches. In this context, the followed process needs the evaluation of the seriousness and the sizes of the problem and determination of the methods and the tools that should be used in this struggle. This perios that should be followed in the struggle against crime mainly consists of the natural, scientific methods and approaches. To struggle effectively against all types of crimes and to prevent their occurance again, all the methods and the approaches that should be followed are determined in this period. In this context, the prevention period is made of the practical application of the Lewin's five stage social research period that he found in the 1940s. These stages are as follows: (Geleri, 2010: 26)

1. Collecting the datas and determining the problem: Collecting all the datas about a specific problem's condition and the size of this problem and drawing a clear Picture of the actual problem.

2. Analysis of the datas: Determination of the physical and the conditional terms that ease the crimes and their analysis.

3. Revision of preventive measures and planning: About the preventive measures and the tools that will eliminate the physical conditions which pave the way for the crimes, including the costs, a systematic work should be done.

4. Choosing the best plan and its application: Choosing the best promising, applicable and economical preventive actions among the occured alternative projects and their application.

5. Monitoring the results and their assesment: Monitoring the results of the applied preventive actions and their consequences and disseminate the experiences to the related person and the institutions benefits ( Bese and Geleri, 2013: 44 ). 
f) Crime Prevention Techniques in Turkey: First of all, the issues that led to crime should be determined and the required studies to eliminate these should be done. If we see the society as a living organism, there can be various structures in the various regions of the country and even in the same province, monotony can not be achieved; so the appropriate models for the social structure should be developed. While duing these, all the education and welfare organizations, NGO's, local governments, meaining that all the stakeholders should work in coordination (Geleri, 2010 : 225).

1. By the physical arrangements, difficult and deter from commiting crimes: Preventive patrol services ( foot motorized- bicycle etc), Civil patrols ( such as security teams ), Security cameras ( city surveillance cameras - Mobese ), Reactive Neighbouring Programs, Private Security Guards and Systems, arrengements in the physical environment ( Ambient lighting, parking, alarm system, solid doors and locks, controlled flow of traffic), regular zoning plans, deterrence can be achieved (Geleri, 2010: 25).

2. Citizen awareness : District Meetings, works towards Schools (students, teachers, parents, administrators), Elderly Mom and Dad studies, works for the Public Employees can be achieved by Radio-TV-Newspaperpublic spot ads, brochures, and flyers in order to raise public awareness.

3. Help - support to the victims and theirs relatives: Prevention of the crime, in this manner by eliminating the victimization or reducing it to its minimum, eliminating the g-fears and worries about crimes and eliminating the fear of being a victim or reducing it to its minimum, increasing the public awareness and the biophilia, eliminating the negative effects of the crimes on the victims or reducing it to its minimum, giving the social, psychological, economic and legal supports to the victims and by decarceration of crime victims to the social life, the restoration of social peace is possible ( Geleri, 2010: $31-33$ ).

4. Decarceration of the ex convicts to the social life: The rehabilitation of these people and for the decarceration of them, creating some social projects with all the parts of the society and re taking these ex convicts to the production ( Geleri, 2010: 33 ).

Utilization of Different Models and Practices in the Field of Preventive Policing: We can list them as Patrols (motorized, foot, horse), School Policing, Specific Zones, Technical and Physical Inspection of the Streets and the Crime Scenes, Security Teams, 
Peace Meetings, "Broken Windows" (not ignoring even the smallest details, to be dealt with each types of guilt), "Zero Tolerance", "Intelligance - Led Policing", "Community Policing", "Problem Oriented Policing", Police and Neighbour Safety, Rehabilitation of the Criminals and Decarceration of the ex convicts, "Tipping Point", the Monetary Size of the Crime and its Analysis.

\section{CONCLUSION}

Prevention of crime is not an easy subject to be left to the judicial and legal officials. If all the citizens and the parts do not participate in this process, any success or progress can not be achieved in the Prevention of Crime. Before improving a model a social analysis must be made. There is no rule that the models which are applied in the various countries of the world will also be successful every time in every place.

In todays society, before the emergence of crime, prevention and protection of the crime and protection of the social costs and a feeling of confidence and preventive security services gained so much importance. In addition to this, the social awareness about the struggle against crime and delinquency and not only by the security forces but also by the supports of all the parts of the society, this turns into a more systematic fight. In this study, an overall struggle has been studied about the crime and the delinquency by the participation of all parts of the society especially by the NGO's.

\section{REFERENCES}

Aydın, Ahmet Hamdi (2002). "Meşruiyet ve Polis", Türkiye'de Devlet Toplum ve Polis, (Ed.) Turgut Göksu ve Hasan Huseyin Çevik (Ankara: Seçkin Yayınları.

Bahadır, Gürbüz, (1985). “Büyükşehir Düzeyinde Kolluk Hizmetlerinin Örgütlenme ve Yürütülmesi”, Ankara: Gazi Üniversitesi (Yayınlanmamış Master Tezi)

Billante, Nicolle (2003). "The Beat Goes On: Policing for Crime Prevention", The Center For Independent Studies, Issue Analysis, No: 38. Australia.

Binniger, Clemens ve G. Dreher, (2004). "New York Şehri Polis Departmanın Suçla Mücadelesindeki Başarısı-New York’tan Öğrenmek”, Çev. Recep TAYFUN, Polis Dergisi, Say1 42: 249-268.

Demir, M. Faruk, (2002). “21. yy’da Türkiye İçin Yeni Bir Milli Güvenlik SiyasetiStratejik Öneriler Belgesi”, Yüksek Strateji Merkezî Yayınları, İstanbul.

Erdem Elçin ve başk. (2001). “Küreselleşme (Globalleşme) Nedir?”, http://

hazirlik2.emu.edu.tr/yonca/kuresel.htm 20.05.2001

Geleri Aytekin, (2010). "Şehirlerde Suç Önleme Politikalarının Geliştirilmesi”

Polis Bilimleri Dergisi, Cilt:12 (3), ss.23-39

Geleri, Aytekin, (2003). Önleyici Polislik, Ankara: Seçkin Yayınevi.

Gleizal, Jean J., J. Gatti-Domenach ve C. Journes, (2000). "Batı Demokrasilerinde 
U. Ayhan

Polis", Çev. Mustafa Kandemir, Ankara: Temiz Yayınları.

London Metropolitan Polica Authority, www.mpa.gov.uk/ downloads/ about/ translation/ turkish.pdf 21.12.2005

NYPD'deki Polis Sayısı, http://www.nyc.gov/html/nypd/ html/misc/ pdfaq2.html \# 41, 20.01.2006

Reno, Janet - D. Marcus - M. L. Leary - N. E. Gist, (2000). "Investing Wisely In Crime Prevention International Experiences'”', I. Waller, D. Sansfaçon (Ed.) Crime Prevention Series 1, Montreal, Quebeck, Canada: International Centre for the Prevention of Crime. http//www. ncjrs.org/ pdffiles1/bja/182412.pdf 